\title{
Spiroplasma poulsonii sp. nov., a new species associated with male-lethality in Drosophila willistoni, a neotropical species of fruit fly
}

\author{
David L. Williamson, ${ }^{1} \dagger$ Bungo Sakaguchi, ${ }^{2}$ Kevin J. Hackett, ${ }^{3}$ \\ Robert F. Whitcomb, ${ }^{4} \ddagger$ Joseph G. Tully, ${ }^{5}$ Patricia Carle, ${ }^{6}$ Joseph M. Bové, ${ }^{6}$ \\ Jean R. Adams, ${ }^{3}$ Meghnad Konai ${ }^{3} \S$ and Roberta B. Henegar ${ }^{3}$
}

Author for correspondence: David L. Williamson. Tel: +1 516724 0897. Fax: +1 5164443947. e-mail: dwmson@physiology.pnb.sunysb.edu

1 Department of Anatomical Sciences, State University of New York, Stony Brook, NY 11794, USA

2 Faculty of Agriculture, Kyushu University, Fukuoka, Japan

3.4 Insect Biocontrol Laboratory ${ }^{3}$ and Vegetable Laboratory 4 US Department of Agriculture, Beltsville, MD 20705, USA

5 Mycoplasma Section, Laboratory of Molecular Microbiology, National Institute of Allergy and Infectious Diseases, Frederick Cancer Research Facility, Frederick, MD 21702, USA

6 Laboratoire de Biologie Cellulaire et Moléculaire, Institut National de la Recherche Agronomique and Université de Bordeaux II, 33883 Villenave d'Ornon Cedex, France
Progenies from some wild-caught females of Drosophila willistoni and three other sibling species are entirely female. The proclivity for production of unisexual female progeny by these flies was named the sex ratio (SR) trait and was originally thought to be genetic. However, experiments in the laboratory of Donald F. Poulson in the early 1960s demonstrated that this 'trait' was vertically transmitted and infectious, in that it could be artificially transferred by injection from infected females to non-infected females. Motile, helical micro-organisms were observed in females showing the trait. In 1979, the SR organisms were designated as group II in the informal spiroplasma classification system. The organisms proved to be extremely fastidious, but were eventually cultivated in a very complex cell-free medium (H-2) after initial co-cultivation with insect cells. Cultivation in the $\mathrm{H}-2$ medium and the subsequent availability of a triply cloned strain (DW-1') permitted comparative studies. Cells of strain DW-1' were helical, motile filaments $200-250 \mathrm{~nm}$ in diameter and were bound by a single trilaminar membrane. Cells plated on $1.8 \%$ Noble agar formed small satellite-free colonies $60-70 \mu \mathrm{m}$ in diameter with dense centres and uneven edges. The temperature range for growth was 26-30 ${ }^{\circ} \mathrm{C}$; optimum growth occurred at $30^{\circ} \mathrm{C}$, with a doubling time in $\mathrm{H}-2$ medium of $15.8 \mathrm{~h}$. The strain passed through filters with $220 \mathrm{~nm}$, but not $100 \mathrm{~nm}$, pores. Reciprocal serological comparisons of strain DW-1' with representatives of other spiroplasma groups showed an extensive pattern of one-way crossing when strain DW-1 ${ }^{\top}$ was used as antigen. However, variable, usually low-level reciprocal cross-reactions were observed between strain DW$1^{\top}$ and representatives of group I sub-groups. The genome size of strain DW-1 was $2040 \mathrm{kbp}$, as determined by PFGE. The G+C content was $26 \pm 1 \mathrm{~mol} \%$, as determined by buoyant density and melting point methods. The serological and molecular data indicate that strain DW-1T is separated from group $I$ representative strains sufficiently to justify retention of its group status. Continued group designation is also indicated by the ability of SR spiroplasmas to induce male lethality in Drosophila, their vertical transmissibility and their extremely fastidious growth requirements. Group II spiroplasmas, represented by strain DW-1' (ATCC $43153^{\top}$ ), are designated Spiroplasma poulsonii.

Keywords: Spiroplasma poulsonii sp. nov., mollicute, sex ratio, Drosophila willistoni

†Present address: 4 Galahad Lane, Nesconset, NY 11767-2220, USA.

†Present address: Carl Hayden Bee Research Center, USDAARS, 2000 E Allen Road, Tucson, AZ 85719, USA.

\$Present address: 9125 Tymat Court, Laurel, MD 20723, USA.

Abbreviation: SR, sex ratio. 


\section{INTRODUCTION}

A curious relationship between spiroplasmas and insects occurs in natural populations of four closely related neotropical species of Drosophila. In collections of flies of the Drosophila willistoni group from tropical South America and islands of the Antilles, single females were found whose progenies consisted of only daughters (Poulson, 1963). This trait, the sex ratio (SR) trait, is widely distributed among members of the $D$. willistoni species group: $D$. willistoni from Jamaica and Brazil; Drosophila nebulosa from Haiti and Brazil; Drosophila equinoxialis subsp. equinoxialis from Brazil and subsp. caribbensis from Puerto Rico, the Dominican Republic and Jamaica; and Drosophila paulistorum from Colombia, Brazil and the West Indies. Early studies of the SR trait conducted in the laboratory of Professor Donald F. Poulson at Yale University demonstrated that the SR trait in the $D$. willistoni species group was maternally (vertically) inherited and infectious, in that it could be artificially transferred by injection from infected females to noninfected females, who then transmitted the trait to their daughters (Malogolowkin \& Poulson, 1957; Malogolowkin et al., 1959; Sakaguchi \& Poulson, 1963). An extensive review of the SR trait in Drosophila and the organisms that induce it was published in 1979 (Williamson \& Poulson, 1979).

In 1960, one of us (B. Sakaguchi), during a postdoctoral fellowship in Professor Poulson's laboratory, discovered the infectious nature of the SR trait. Using a glass micropipette, a small sample of haemolymph was aspirated from $D$. willistoni females producing unisexual (female) progenies and placed under a drop of crown immersion oil on a microscope slide and observed, first under ordinary light microscopy, by which nothing was visible, and subsequently under phase-contrast microscopy. Even though the optics of this microscope provided much less contrast than the optics of the dark-field microscopes currently used for spiroplasma observation, Sakaguchi was surprised to find that the haemolymph was teeming with small filamentous organisms. In freshly mounted preparations, waves of helicoidal movement could be seen to pass along the length of the filaments, giving them a regular spiral appearance. Fixation of such preparations over formaldehyde vapour, followed by various staining procedures, suggested that the organisms were similar in size and general aspect to spirochaetes in the genus Treponema (Poulson \& Sakaguchi, 1961). Hence, the organisms were referred to as 'sex ratio spirochaetes', until they were shown (Williamson, 1969; Williamson \& Whitcomb, 1974) by electron microscopic examination of fixed and negatively stained cells to be devoid of axial filaments and outer envelopes - structures characteristic of spirochaetes. Instead, the SR organisms proved to be structurally similar to spiroplasmas associated with corn stunt disease (Davis et al., 1972; Chen \& Liao, 1975; Williamson \& Whitcomb, 1975) and stubborn disease of citrus (Cole et al., 1973).
Prior to the establishment of a cloned isolate of the $D$. willistoni SR spiroplasma, studies on the organisms were performed using suspensions of spiroplasmas in physiological saline, which were prepared from small samples of haemolymph aspirated from $D$. willistoni flies carrying the SR trait. Microscopic enumeration of haemolymph dilutions indicated that haemolymph titres in $D$. willistoni were about $1 \times 10^{11} \mu \mathrm{l}^{-1}$. Suspensions of organisms from fly haemolymph were used to produce an antiserum in rabbits, and to determine the $\mathrm{G}+\mathrm{C}$ content of DNA from the uncloned organisms. Vigorous attempts were made to cultivate the SR spiroplasma, but even though certain medium formulations permitted them to be maintained for varying periods, none provided the necessary factors for growth (Williamson et al., 1983). Finally, however, in 1986, Hackett and collaborators reported that they had successfully grown and cloned the $D$. willistoni SR spiroplasma (Hackett et al., 1986). In these studies, the SR spiroplasma was first grown in co-culture with a lepidopteran cell line and subsequently in cell-free culture in a new medium, H-2 (Hackett et al., 1986). Cultivation of the organisms permitted them to be cloned, and the DW-1 $1^{\mathrm{T}}$ strain was selected for further study. After injection of a suspension of strain DW-1 ${ }^{\mathrm{T}}$ spiroplasmas into Drosophila pseudoobscura Piñon Normal strain females, their progenies became entirely female (Williamson et al., 1989). However, the cloned organisms had lost the ability to be vertically transmitted.

Reciprocal spiroplasma deformation and metabolism inhibition tests involving strain DW-1 ${ }^{\mathrm{T}}$ and representative strains of all other groups and sub-groups have now been completed. These tests showed strong patterns of one-way cross-reactions when strain DW$1^{\mathrm{T}}$ was used as antigen (Williamson et al., 1998). Some reciprocal crossing patterns between strain $\mathrm{DW}-1^{\mathrm{T}}$ and group I spiroplasmas were observed, but the patterns were not as strong as most intragroup reactions among group I spiroplasmas. The phylogenetic relationship of strain DW-1 ${ }^{\mathrm{T}}$ to other spiroplasmas was clarified by the studies of Weisburg et al. (1989). These studies showed that group I and group II spiroplasmas were more closely related to each other than to other spiroplasma groups, but nonetheless had significant sequence dissimilarity. The status of strain DW $-1^{\mathrm{T}}$ as the representative strain of group II spiroplasmas is therefore justified on the basis of molecular and serological data. In addition, its unique biological characteristics - host specificity, pathogenicity for male progeny, transovarial transmission and fastidious growth requirements - also augur for its group status. In this report we present the results of characterization studies of strain DW-1 ${ }^{\mathrm{T}}$ in fulfillment of the minimal standards for new species descriptions for strains classified in the class Mollicutes (International Committee on Systematic Bacteriology Subcommittee on the taxonomy of Mollicutes, 1995). Strain DW-1 ${ }^{\mathrm{T}}$ is hereby designated as the type strain (ATCC $43153^{\mathrm{T}}$ ) of a new species, Spiroplasma poulsonii, named in 


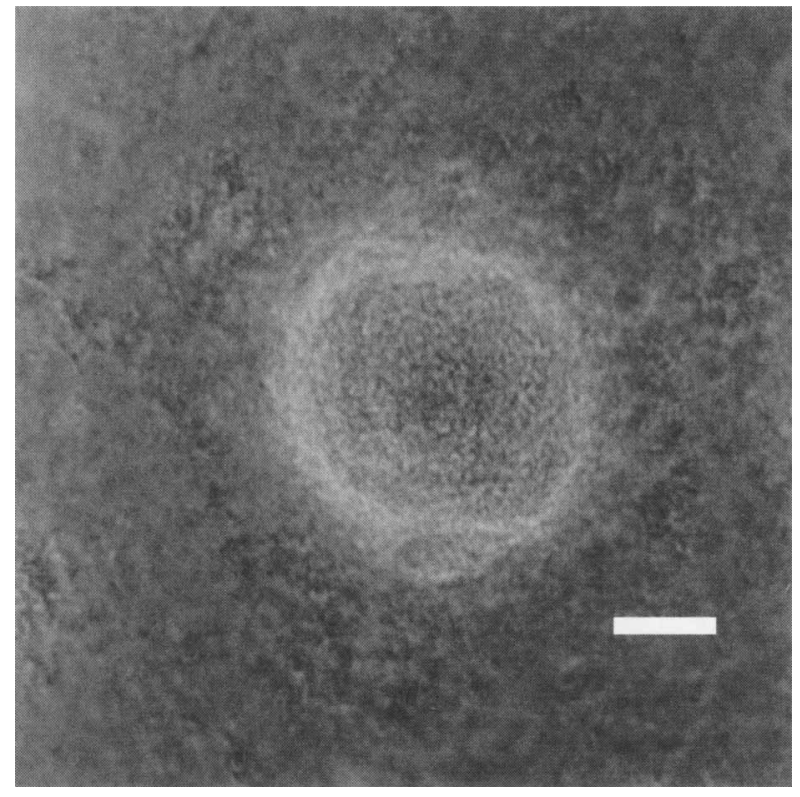

Fig. 1. Colony of strain $\mathrm{DW}-1^{\top}$ on $\mathrm{H}-2$ medium supplemented with $1.8 \%$ Noble agar after $32 \mathrm{~d}$ at $26^{\circ} \mathrm{C}$ under aerobic conditions with $5 \% \mathrm{CO}_{2}$. Bar, $20 \mu \mathrm{m}$.

memory of Professor Donald F. Poulson, in whose laboratory at Yale University SR organisms were first studied.

\section{METHODS}

Spiroplasma strains. Strain DW- $1^{\mathrm{T}}$ was cultivated (Hackett et al., 1986) from a haemolymph suspension obtained from D. pseudoobscura (Piñon Normal strain) female flies artificially infected by injection of naturally infected Barbados3 strain $D$. willistoni SR haemolymph. Briefly, $2 \cdot 5 \mu \mathrm{l}$ haemolymph from the infected females was collected by glass needle and transferred to $500 \mu \mathrm{l}$ M1D medium. In $D$. pseudoobscura, SR organisms reach a titre of about $1 \times 10^{11} \mu \mathrm{l}^{-1}$, so the initial cell titre in the primary culture was about $5 \times 10^{10} \mu \mathrm{l}^{-1}$. An aliquot of this suspension was mixed with lepidopteran cell culture medium (DCCM) (Hackett \& Lynn, 1995) and further aliquoted to microtitre wells containing embryo-derived cells from the cabbage looper (Trichoplusia ni) cell line (IPLB-TN-R ${ }^{2}$ ) (Rochford et al., 1984). Primary isolation was accomplished in co-culture with $T . n i$ cells initially growing in TNM-FH medium (Hackett et al., 1986). Organisms growing in these cultures were eventually adapted to grow in the cell-free $\mathrm{H}-2$ medium (Hackett et al., 1986). Growth was evaluated by enumeration of helical cells in 3 or $5 \mu \mathrm{l}$ samples under dark-field microscopy (Williamson, 1969). After nine co-culture passages, the SR organisms were adapted to grow in cell-free $\mathrm{H}-2$ medium. At passage 20 , the spiroplasmas were triply cloned by the limiting dilution method of Whitcomb \& Hackett (1986). One triply cloned strain at passage 23 was selected and designated strain DW-1 ${ }^{\mathrm{T}}$ (ATCC $43153^{\mathrm{T}}$ ). A batch culture was prepared, aliquoted to ampules and lyophilized. Rehydrated cultures were used for the characterization studies reported here. Representatives of the strains of all currently recognized groups and sub-groups, including the type strains of named species (Williamson et al., 1998), were utilized for these comparative studies.

Culture medium and cultivation techniques. H-2 medium (Hackett et al., 1986), a combination of 1 part DCCM (Hackett \& Lynn, 1995), 2 parts M1D (Whitcomb, 1983) and 1 part modified Grace's Insect Medium (TNM-FH) (Hackett \& Lynn, 1985), supplemented with $15 \%(\mathrm{v} / \mathrm{v})$ foetal bovine serum and containing $800 \mathrm{U}$ penicillin $\mathrm{ml}^{-1}$, was used as the growth medium for all tests involving strain $\mathrm{DW}-1^{\mathrm{T}}$. Batch cultures of cells in this medium were prepared in $9 \mathrm{ml} \mathrm{H}-2$ medium. About $10 \mathrm{~d}$ were required to reach maximum titre (about $1 \times 10^{7} \mathrm{ml}^{-1}$, initially). To prepare solid H-2 medium, $8 \%$ (w/v) Noble agar (Difco) was added to the autoclavable fraction of $\mathrm{M} 1 \mathrm{D}$, microwaved to melt the agar, equilibrated at $56^{\circ} \mathrm{C}$ and added to $\mathrm{H}-2$ broth medium at $56^{\circ} \mathrm{C}$ to produce a final agar concentration of $1.8 \%$. Cultures of strain $\mathrm{DW}-1^{\mathrm{T}}$ on solid media were incubated at $26{ }^{\circ} \mathrm{C}$, either aerobically without added $\mathrm{CO}_{2}$ or with $5 \%(\mathrm{v} / \mathrm{v}) \mathrm{CO}_{2}$ (Enhanced $\mathrm{CO}_{2}$ Gaspak system, BBL Microbiology Systems) or anaerobically (Hydrogen and $\mathrm{CO}_{2}$ Gaspak system). The SP-4 and M1D medium formulations were used for the cultivation of other spiroplasma strains. Temperature requirements for growth were determined by the method of Konai et al. (1996).

Morphological studies. The motility and gross morphology of strain DW- $1^{\mathrm{T}}$ cells were determined by observing them in 3-5 $\mu \mathrm{l}$ samples of broth cultures under dark-field illumination at $\times 800-1250$. For electron microscopic studies of the fine structure of strain $\mathrm{DW}-1^{\mathrm{T}}$ cells, previously published procedures (Williamson, 1983) were followed.

Sterol requirements. The sterol requirement for growth was evaluated by determining the protein yield of strain DW-1 ${ }^{\mathrm{T}}$ grown in serum-free $\mathrm{H}-2$ broth supplemented with increasing amounts of foetal bovine serum following procedures previously described (Tully, 1983b).

Tests for biological and biochemical properties. The extremely fastidious nature of strain $\mathrm{DW}-1^{\mathrm{T}}$ precluded adaptation in base broth media usually employed for the demonstration of glucose fermentation and hydrolysis of arginine and urea (Aluotto et al., 1970). The filtration characteristics were measured in $\mathrm{H}-2$ broth by procedures previously reported (Tully, 1983a).

Serological tests. Cell pellets of organisms were prepared by growing bulk cultures in $500 \mathrm{ml} \mathrm{H}-2$ media. Homologous antiserum against strain $\mathrm{DW}-1^{\mathrm{T}}$ was produced in rabbits as previously described (Williamson et al., 1979). Hyperimmune antisera against all established Spiroplasma species, groups and sub-groups (Williamson et al., 1998) were obtained from reference collections at the USDA Beltsville Agricultural Research Center, Beltsville, MD, USA and the National Institute of Allergy and Infectious Diseases laboratory, Frederick, MD, USA. These antisera and their respective antigens were tested against strain $\mathrm{DW}-1^{\mathrm{T}}$ in reciprocal deformation and metabolism inhibition tests (Williamson et al., 1978, 1979).

Genome analysis. The techniques for extraction and purification of chromosomal DNA from strain DW-1 ${ }^{\mathrm{T}}$ have been described previously (Carle et al., 1983a). The DNA $\mathrm{G}+\mathrm{C}$ composition of strain $\mathrm{DW}-1^{\mathrm{T}}$ was determined by buoyant density and melting temperature following the procedures of Carle et al. (1983b). $\mathrm{G}+\mathrm{C}$ determinations were performed first on pelleted uncloned organisms and 
later on pelleted organisms of strain DW-1 $1^{\mathrm{T}}$. The genome size of strain DW- $1^{\mathrm{T}}$ was determined by PFGE, employing techniques described earlier (Carle et al., 1995). Purified DNA from Spiroplasma citri (genome size $1820 \mathrm{kbp} ; \mathrm{G}+\mathrm{C}$ content $26 \pm 1 \mathrm{~mol} \%$ ) was used as a reference in all procedures (Carle et al., 1995).

\section{RESULTS AND DISCUSSION}

\section{Cultural and morphological properties}

Strain DW- $1^{\mathrm{T}}$ grew to titres of $10^{7}-10^{8}$ organisms $\mathrm{ml}^{-1}$ in $\mathrm{H}-2$ medium. All attempts to adapt strain $\mathrm{DW}-\mathrm{1}^{\mathrm{T}}$ in other media commonly employed for spiroplasma cultivation (Whitcomb, 1983) were unsuccessful: organisms failed to grow beyond the first 10-fold dilution when inoculated into M1D or SP-4 media or into basal broth (BSR) medium containing either $10 \%$ foetal bovine serum or $1 \%(\mathrm{v} / \mathrm{v})$ bovine serum fraction. The doubling time for strain $\mathrm{DW}-1^{\mathrm{T}}$ growing in $\mathrm{H}-2$ medium was $15.8 \mathrm{~h}$ at $30^{\circ} \mathrm{C}$, its optimum temperature for growth. This is one of the longest doubling times for spiroplasmas in culture. Strain DW $-1^{\mathrm{T}}$ grew on solid medium on $1.8 \%$ Noble agar plates incubated aerobically with $5 \% \mathrm{CO}_{2}$ at $26^{\circ} \mathrm{C}$. Colonies were first evident $32 \mathrm{~d}$ after inoculation; fully developed colonies were small $(60-70 \mu \mathrm{m}$ in diameter) with dense centres and uneven edges (Fig. 1); no satellite colonies were observed.

Dark-field microscopy of broth cultures of strain DW$1^{\mathrm{T}}$ showed motile helical filaments with four or more turns. Electron microscopy of thin sections of pellets of uncloned organisms from insect haemolymph (Williamson \& Whitcomb, 1974) and of strain DW-1 ${ }^{\mathrm{T}}$ (Fig. 2) revealed the presence of filamentous cells $200-250 \mathrm{~nm}$ in diameter bounded by a single trilaminar membrane.

\section{Sterol requirement}

The amounts of protein contained in pellets of strain DW- $1^{\mathrm{T}}$ inoculated into $\mathrm{H}-2$ medium supplemented with 15,10 and $2 \%$ foetal bovine serum were $0.52,0.54$ and $0.22 \mathrm{mg}$ per $100 \mathrm{ml}$, respectively. No protein production or colour change (see below) was observed in media containing $0 \%$ foetal bovine serum, and no spiroplasma cells were found in 50 fields examined under dark-field microscopy ( $5 \mu$ l culture sample). These results indicate that serum or sterol is required for growth of strain DW-1 ${ }^{\mathrm{T}}$.

\section{Biochemical and biological properties}

Growth of strain DW-1 ${ }^{\mathrm{T}}$ in $\mathrm{H}-2$ medium, which contains $0.025 \%(\mathrm{v} / \mathrm{v})$ phenol red as a $\mathrm{pH}$ indicator, is accompanied by a colour shift from red-orange to yellow as the number of cells increases, indicating that acid is produced from one or more of the various substrates contained in the medium. A subsequent shift back to red-orange colour, as is observed in

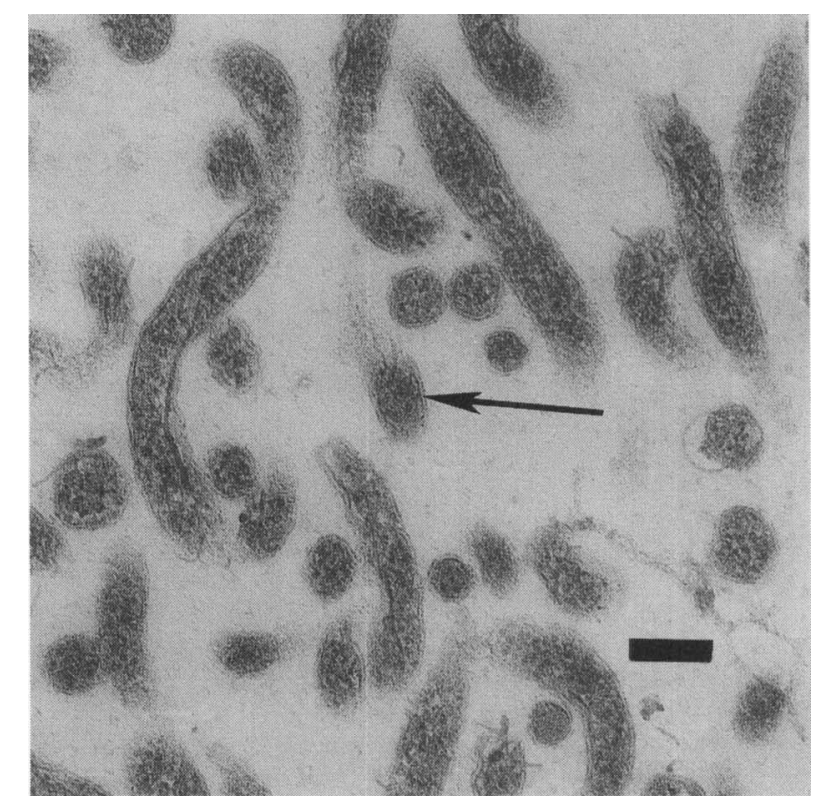

Fig. 2. Electron micrograph of a sectioned and stained pellet of strain DW-1 ${ }^{\top}$ cells. The section was stained with $2 \%$ aqueous uranyl acetate and Reynold's lead citrate. The arrow indicates the unit membrane. Bar, $200 \mathrm{~nm}$.

cultures of strains that utilize arginine, has not been observed. Filtration of strain $\mathrm{DW}-1^{\mathrm{T}}$ broth cultures with a cell titre of $1 \times 10^{7}$ colour-changing units (CCUs) $\mathrm{ml}^{-1}$ through 450,300 and $220 \mathrm{~nm}$ pore-size membrane filters resulted in cell titres of $10^{7}, 10^{6}$ and $10^{6} \mathrm{CCUs} \mathrm{ml}^{-1}$, respectively. There were no viable cells in the $100 \mathrm{~nm}$ pore-size membrane filtrate. The end point of the unfiltered dilution series was reached after $70 \mathrm{~d}$ culture.

\section{Serological tests}

The results of reciprocal spiroplasma deformation (DF) and metabolism inhibition (MI) tests of strain $\mathrm{DW}-1^{\mathrm{T}}$ versus representatives of the currently recognized strains of the groups and sub-groups of spiroplasmas were published in a recent revision of the group classification of the genus Spiroplasma (Williamson et al., 1998). Serological data pertaining to strain DW $-1^{\mathrm{T}}$ are presented in Table 1 . In the DF test, when strain DW-1 ${ }^{\mathrm{T}}$ was used as an antigen, titres of 20-640 were obtained with the antisera to group I representatives; four sera to other spiroplasma groups cross-reacted at low levels. Serum directed against strain DW $-1^{\mathrm{T}}$ reacted with antigens from six of the group I representatives, with a maximum titre of 80 , and with PUP-1 ${ }^{T}$ (group XIX). The titre in the homologous reaction was 1280 . In the $\mathrm{MI}$ test, when strain DW- $1^{\mathrm{T}}$ was used as antigen, titres of $162-39000$ were observed against group I antisera. However, some reactivity was observed with almost all spiroplasma antisera. Outside group I, a titre of 1458 was 
Table 1. Serological reactivities of the group II spiroplasma strain DW-1 ${ }^{T}$

Antigen and antisera of the strains were tested in all heterologous combinations against all known and putative groups and subgroups. All cross-reactions were negative (-) except where shown. Values in the 'Antigen' columns are reciprocals of the end points when antiserum to $\mathrm{DW}-1^{\mathrm{T}}$ was used against the designated antigen. Values in 'Antiserum' columns are reciprocals of end points when DW- $1^{\mathrm{T}}$ was used as antigen against heterologous antiserum.

\begin{tabular}{|c|c|c|c|c|c|}
\hline \multirow[t]{2}{*}{ Group } & \multirow[t]{2}{*}{ Strain } & \multicolumn{2}{|c|}{ Deformation } & \multicolumn{2}{|c|}{ Metabolism inhibition } \\
\hline & & Antigen & Antiserum & Antigen & Antiserum \\
\hline $\mathrm{I}-1$ & Maroc R8A2 $2^{\mathrm{T}}$ & 20 & 20 & 162 & - \\
\hline $\mathrm{I}-2$ & BC- $3^{\mathrm{T}}$ & 160 & - & 486 & 54 \\
\hline $\mathrm{I}-3$ & $\mathrm{E} 275^{\mathrm{T}}$ & 160 & 20 & 486 & - \\
\hline I-4 & $277 \mathrm{~F}$ & 160 & 80 & 4374 & - \\
\hline $\mathrm{I}-5$ & LB-12 & 160 & - & 39000 & - \\
\hline I-6 & M55 & 320 & 20 & 4374 & - \\
\hline I-7 & N525 & 320 & 40 & 39000 & - \\
\hline I-8 & $\mathrm{P} 40^{\mathrm{T}}$ & 640 & 20 & 1458 & 54 \\
\hline II & DW-1 ${ }^{\mathrm{T}}$ & $1280^{*}$ & $1280^{*}$ & $>117000^{*}$ & $>117000^{*}$ \\
\hline III & $23-6^{\mathrm{T}}$ & - & - & 18 & - \\
\hline IV & $\mathrm{B} 31^{\mathrm{T}}$ & 20 & - & 54 & - \\
\hline VI & $\mathrm{Y} 32^{\mathrm{T}}$ & - & - & 18 & - \\
\hline VII & MQ-1 ${ }^{\mathrm{T}}$ & - & - & 54 & - \\
\hline VIII-1 & $\mathrm{EA}-1^{\mathrm{T}}$ & - & - & 54 & - \\
\hline VIII-2 & $\mathrm{DF}-1^{\mathrm{T}}$ & - & - & 1458 & - \\
\hline IX & $\mathrm{CN}-5^{\mathrm{T}}$ & - & - & 162 & - \\
\hline $\mathrm{X}$ & AES-1 $1^{T}$ & - & - & 486 & - \\
\hline XII & $\mathrm{DU}-1^{\mathrm{T}}$ & - & - & 18 & - \\
\hline XIII & Ar- $1343^{T}$ & - & - & 54 & - \\
\hline $\mathrm{XV}$ & I-25 & - & - & 54 & - \\
\hline XVI-1 & $\mathrm{CC}-1^{\mathrm{T}}$ & 20 & - & - & - \\
\hline XVI-2 & CB-1 & - & - & 54 & - \\
\hline XVI-3 & Ar-1357 & - & - & 54 & - \\
\hline XVIII & $\mathrm{TN}-1^{\mathrm{T}}$ & 40 & - & 18 & - \\
\hline XIX & PUP- $1^{\mathrm{T}}$ & - & 40 & 18 & - \\
\hline $\mathrm{XX}$ & LD- $1^{\mathrm{T}}$ & - & - & 54 & 18 \\
\hline XXI & W115 & - & - & 18 & - \\
\hline XXII & CT- $1^{\mathrm{T}}$ & - & - & 18 & - \\
\hline XXIII & TG- $1^{\mathrm{T}}$ & - & - & 54 & - \\
\hline XXIV & $\mathrm{CCH}^{\mathrm{T}}$ & - & - & 18 & - \\
\hline XXV & CUAS- $1^{\mathrm{T}}$ & 20 & - & 18 & - \\
\hline XXVI & PLHS- $1^{\mathrm{T}}$ & - & - & - & 54 \\
\hline XXIX & TIUS-1 & - & - & 18 & - \\
\hline $\mathrm{XXX}$ & BIUS-1 & - & - & 18 & - \\
\hline XXXI & HYOS-1 ${ }^{\mathrm{T}}$ & - & - & 54 & - \\
\hline XXXII & TABS- $2^{\mathrm{T}}$ & - & - & 18 & - \\
\hline XXXIII & TAUS- $1^{\mathrm{T}}$ & - & - & 18 & - \\
\hline XXXIV & BARC 1901 & - & - & 486 & - \\
\hline Ungrouped & BARC 2649 & - & - & 1458 & - \\
\hline
\end{tabular}

${ }^{*}$ Homologous titres of strain DW- $1^{\mathrm{T}}$ in the respective test system. The reaction, obtained only once, is listed in each column for completeness.

obtained when strain DW-1 $1^{\mathrm{T}}$ reacted with serum against strain DF- $1^{\mathrm{T}}$ (sub-group VIII-2; Spiroplasma chrysopicola) and with serum against ungrouped strain BARC 2649 . When strain DW- $1^{\mathrm{T}}$ was represented as antiserum, growth of only two group I strains (I-2 and
I-8) was inhibited by antiserum directed against strain DW $-1^{\mathrm{T}}$. The homologous titre in the MI test was $>117000$. When the DF and MI tests are considered together, only one set of reactions, those with subgroup I-8 (Spiroplasma phoeniceum) showed complete 
reciprocal cross-reactivity, and then only at low titre. This profile of serological cross-reactivity is considerably weaker than that observed among the sub-groups of group I (Whitcomb et al., 1982), suggesting a more distant link between group I sub-groups and strain $\mathrm{DW}-1^{\mathrm{T}}$ than among the group I sub-groups.

\section{Genome size and DNA base composition}

The base composition ( $\mathrm{G}+\mathrm{C}$ content) of strain DW$1^{\mathrm{T}}$ was $26 \pm 1 \mathrm{~mol} \%$. The same value was obtained from analysis of DNA from uncloned organisms. The undigested linear DNA of strain DW-1 $1^{\mathrm{T}}$ was $2040 \mathrm{kbp}$, as determined by PFGE.

\section{Habitat and pathogenicity}

Haemolymph is the normal habitat of the $D$. willistoni SR spiroplasma, where it grows to titres of approximately $10^{11}$ organisms $\mu 1^{-1}$. The ability of strain DW$1^{\mathrm{T}}$ to grow in haemolymph, to eliminate male progeny from injected females and to be vertically transmitted to the subsequent generation was tested (Williamson et al., 1989) by injection of $D$. pseudoobscura females with a suspension of strain $\mathrm{DW}-1^{\mathrm{T}}$ spiroplasmas at the sixteenth passage after triple cloning (39 total passages). In these studies, strain $\mathrm{DW}-1^{\mathrm{T}}$ was capable of growing in the haemolymph and causing the elimination of male progeny, but had lost the ability to be vertically transmitted.

Properties described herein for strain DW-1 ${ }^{\mathrm{T}}$ fulfil the proposed criteria (International Committee on Systematic Bacteriology Subcommittee on the taxonomy of Mollicutes, 1995) for species of the class Mollicutes, including the absence of a cell wall, filterability, the lack of reversion to walled bacteria when grown in antibiotic-free media, and penicillin resistance. The helicity and motility of strain DW- $1^{\mathrm{T}}$ place it in the order Entomoplasmatales and the family Spiroplasmataceae (Tully et al., 1993). The results of the serological comparison of strain DW-1 ${ }^{\mathrm{T}}$ with other Spiroplasma species and groups indicate that strain $\mathrm{DW}-\mathrm{1}^{\mathrm{T}}$ shares antigens with group I sub-group strains. Most of the cross-reactions involving these antigens were much stronger when strain $\mathrm{DW}-1^{\mathrm{T}}$ served as antigen. Strain $\mathrm{DW}-1^{\mathrm{T}}$, when used as antigen, also cross-reacted with antisera directed against representatives of many other spiroplasma groups. The property of extensive cross-reaction with many antispiroplasma sera has also been observed with Spiroplasma lampyridicola (Stevens et al., 1997), Spiroplasma alleghenense (Adams et al., 1997) and, to a somewhat lesser degree, Spiroplasma platyhelix (Williamson et al., 1997). Levels of cross-reaction greater than the intergroup reactions between groups I and II occur among the sub-groups of group I, but have not prevented the designation of separate species for sub-groups I-1 (S. citri; Saglio et al., 1973); subgroup I-2 (Spiroplasma melliferum; Clark et al., 1985); sub-group I-3 (Spiroplasma kunkelii; Whitcomb et al.,
1986); sub-group I-6 (Spiroplasma insolitum; Hackett et al., 1993); and sub-group I-8 ( $S$. phoeniceum; Saillard et al., 1987). Therefore, minor serological cross-reactivity is not a barrier to separate species designation, even for spiroplasma sub-groups. In the case of the group I sub-groups, species designations were supported by DNA-DNA homology data. In the case of the group II strain DW- $1^{\mathrm{T}}$, separation from the group I spiroplasmas is indicated by the $16 \mathrm{~S}$ rRNA gene sequencing data (GenBank M24483) of Weisburg et al. (1989), which showed substantial sequence dissimilarity between group I and group II strains. This divergence has recently been recalculated (Hurst et al., 1999) and found to be about $2 \cdot 5 \%$. Not only the molecular data, but biological data, including the extremely fastidious growth requirements, host restriction, male lethality and vertical transmissibility of uncloned organisms, indicate that the group II designation of strain DW- $1^{\mathrm{T}}$ should be preserved to reflect its unique status. As a result of the characterization studies described herein, the name Spiroplasma poulsonii is proposed for the group II representative, strain DW-1 $1^{\mathrm{T}}$. The taxonomic description below summarizes the properties of this new species.

\section{Description of Spiroplasma poulsonii sp. nov.}

Spiroplasma poulsonii (poul.son'i.i. M.L. n. poulsonii of Poulson, named in memory of Donald F. Poulson, Professor of Biology at Yale University, in whose laboratory this spiroplasma was discovered and studied intensively).

Cells are motile helical filaments $200-250 \mathrm{~nm}$ in diameter. The membrane-bound cells lack cell walls. Cells plated on $1.8 \%$ Noble agar form small satellitefree colonies $60-70 \mu \mathrm{m}$ in diameter that have dense centres and uneven edges. Chemo-organotroph. Acid is produced during growth in $\mathrm{H}-2$ medium. The temperature range for growth is $26-30^{\circ} \mathrm{C}$, with optimum growth at $30^{\circ} \mathrm{C}$. The doubling time at the optimum temperature in H-2 medium is $15.8 \mathrm{~h}$. Serologically distinct from other established Spiroplasma species. Isolated from the haemolymph of Drosophila pseudoobscura females infected by haemolymph transfer of the Barbados-3 strain of Drosophila willistoni SR organism. Pathogenicity (lethality to male progeny) confirmed by injection into Drosophila pseudoobscura. Vertical transmissibility lost after cultivation and cloning. The $\mathrm{G}+\mathrm{C}$ content of the DNA is $26 \pm 1 \mathrm{~mol} \%$, as determined by buoyant density and melting point methods. The genome size is $2040 \mathrm{kbp}$, as determined by PFGE. The GenBank accession number for the 16S rRNA gene sequence is M24483. The type strain is DW $-1^{\mathrm{T}}$ (=ATCC $43153^{\mathrm{T}}$ ).

\section{REFERENCES}

Adams, J. R., Whitcomb, R. F., Tully, J. G. \& 7 other authors (1997). Spiroplasma alleghenense sp. nov., a new species from the scorpion fly Panorpa helena (Mecoptera: Panorpidae). Int $J$ Syst Bacteriol 47, 759-762. 
Aluotto, B. B., Wittler, R. G., Williams, C. O. \& Faber, J. E. (1970). Standardized bacteriologic techniques for characterization of Mycoplasma species. Int J Syst Bacteriol 20, 35-58.

Carle, P., Saillard, C. \& Bové, J. M. (1983a). DNA extraction and purification. Methods Mycoplasmol 1, 295-299.

Carle, P., Saillard, C. \& Bové, J. M. (1983b). Determination of guanine plus cytosine content of DNA. Methods Mycoplasmol 1, 301-308.

Carle, P., Laigret, F., Tully, J. G. \& Bové, J. M. (1995). Heterogeneity of genome sizes within the genus Spiroplasma. Int J Syst Bacteriol 45, 178-181.

Chen, T. A. \& Liao, C. H. (1975). Corn stunt spiroplasma: isolation, cultivation and proof of pathogenicity. Science 188, 1015-1017.

Clark, T. B., Whitcomb, R. F., Tully, J. G. \& 8 other authors (1985). Spiroplasma melliferum, a new species from the honeybee (Apis mellifera). Int J Syst Bacteriol 35, 296-308.

Cole, R. M., Tully, J. G., Popkin, T. J. \& Bové, J. M. (1973). Morphology, ultrastructure, and bacteriophage infection of the helical mycoplasma-like organism (Spiroplasma citri gen. nov., sp. nov.) cultured from 'stubborn' disease of citrus. J Bacteriol 115, 367-386.

Davis, R. E., Whitcomb, R. F., Chen, T. A. \& Granados, R. R. (1972). Current status of the aetiology of corn stunt disease. In Pathogenic Mycoplasmas (Ciba Foundation Symposium), pp. 205-225. Edited by K. Elliott \& J. Birch. Amsterdam: Associated Scientific Publishers.

Hackett, K. J. \& Lynn, D. E. (1985). Cell-assisted growth of a fastidious spiroplasma. Science 230, 825-827.

Hackett, K. J. \& Lynn, D. E. (1995). Insect cell culture approaches in cultivating spiroplasmas. In Molecular and Diagnostic Procedures in Mycoplasmology, vol. 1, pp. 55-64. Edited by S. Razin \& J. G. Tully. San Diego, CA: Academic Press.

Hackett, K. J., Lynn, D. E., Williamson, D. L., Ginsberg, A. \& Whitcomb, R. F. (1986). Cultivation of the Drosophila sex ratio spiroplasma. Science 232, 1253-1255.

Hackett, K. J., Whitcomb, R. F., Tully, J. G. \& 9 other authors (1993). Spiroplasma insolitum sp. nov., a new species of group I spiroplasma with an unusual DNA base composition. Int $J$ Syst Bacteriol 43, 272-277.

Hurst, G. D. D., Schulenberg, J. H. G., Majerus, T. M. O., Bertrand, D., Zakharov, I. A., Baungaard, J., Volkl, W., Stouthamer, R. \& Majerus, M. E. N. (1999). Invasion of one insect species, Adalia bipunctata, by two different male-killing bacteria. Insect $\mathrm{Mol}$ Biol 8, 133-140

International Committee on Systematic Bacteriology Subcommittee on the taxonomy of Mollicutes (1995). Revised minimum standards for descriptions of new species of the class Mollicutes (Division Tenericutes). Int J Syst Bacteriol 45, 605-612.

Konai, M., Clark, E. A., Camp, M., Koch, A. L. \& Whitcomb, R. F. (1996). Temperature ranges, growth optima, and growth rates of Spiroplasma (Spiroplasmataceae, class Mollicutes) species. Curr Microbiol 32, 314-319.

Malogolowkin, C. \& Poulson, D. F. (1957). Infective transfer of maternally inherited abnormal sex-ratio in Drosophila willistoni. Science 126, 32.

Malogolowkin, C., Poulson, D. F. \& Wright, E. Y. (1959). Experimental transfer of maternally inherited abnormal sex-ratio in Drosophila willistoni. Genetics 44, 59-74.

Poulson, D. F. (1963). Cytoplasmic inheritance and hereditary infections in Drosophila. In Methodology in Basic Genetics,
Appendix III, pp. 404-424. Edited by W. J. Burdette. San Francisco, CA: Holden Day.

Poulson, D. F. \& Sakaguchi, B. (1961). Nature of "sex-ratio" agent in Drosophila. Science 133, 1489-1490.

Rochford, R., Dougherty, E. M. \& Lynn, D. E. (1984). Establishment of a cell line from embryos of the cabbage looper, Trichoplusia ni (Hubner). In Vitro 20, 823-825.

Saglio, P., L'Hospital, M., Laflèche, D., Dupont, G., Bové, J. M., Tully, J. G. \& Freundt, E. A. (1973). Spiroplasma citri gen. and sp. n.: a mycoplasma-like organism associated with "stubborn" disease of citrus. Int J Syst Bacteriol 23, 191-204.

Saillard, C., Vignault, J. C., Bové, J. M. \& 8 other authors (1987). Spiroplasma phoeniceum sp. nov., a new plant-pathogenic species from Syria. Int J Syst Bacteriol 37, 106-115.

Sakaguchi, B. \& Poulson, D. F. (1963). Interspecific transfer of the "sex-ratio" condition from Drosophila willistoni to D. melanogaster. Genetics 48, 841-861.

Stevens, C., Tang, A. Y., Jenkins, E. \& 12 other authors (1997). Spiroplasma lampyridicola sp. nov., from the firefly beetle Photuris pennsylvanicus. Int J Syst Bacteriol 47, 709-712.

Tully, J. G. (1983a). Cloning and filtration techniques for mycoplasmas. Methods Mycoplasmol 1, 173-177.

Tully, J. G. (1983b). Tests for digitonin sensitivity and sterol requirement. Methods Mycoplasmol 1, 355-362.

Tully, J. G., Bové, J. M., Laigret, F. \& Whitcomb, R. F. (1993). Revised taxonomy of the class Mollicutes: proposed elevation of a monophyletic cluster of arthropod-associated mollicutes to ordinal rank (Entomoplasmatales ord. nov.), with provision for familial rank to separate species with nonhelical morphology (Entomoplasmataceae fam. nov.) from helical species (Spiroplasmataceae), and emended descriptions of the order Mycoplasmatales, family Mycoplasmataceae. Int J Syst Bacteriol 43, 378-385.

Weisburg, W. G., Tully, J. G., Rose, D. L. \& 9 other authors (1989). A phylogenetic analysis of the mycoplasmas: basis for their classification. J Bacteriol 171, 6455-6467.

Whitcomb, R. F. (1983). Culture media for spiroplasmas. Methods Mycoplasmol 1, 147-158.

Whitcomb, R. F. \& Hackett, K. J. (1986). Cloning by limiting dilution in liquid media: an improved alternative for cloning mollicute species. Program and Abstracts of the 6th International Congress of the International Organization for Mycoplasmology, Birmingham, AL, 26-31 August 1986, p. 167.

Whitcomb, R. F., Tully, J. G., Clark, T. B., Williamson, D. L. \& Bové, J. M. (1982). Revised serological classification of spiroplasmas, new provisional groups, and recommendations for serotyping isolates. Curr Microbiol 7, 291-296.

Whitcomb, R. F., Chen, T. A., Williamson, D. L. \& 7 other authors (1986). Spiroplasma kunkelii, sp. nov.: characterization of the etiological agent of corn stunt disease. Int J Syst Bacteriol 36 , $170-178$.

Williamson, D. L. (1969). The sex ratio spirochete in Drosophila robusta. Jpn J Genet 44, Suppl. 1, 36-41.

Williamson, D. L. (1983). Specialized electron microscopic techniques for spiroplasmas in plant and insect tissues. Methods Mycoplasmol 1, 71-76.

Williamson, D. L. \& Poulson, D. F. (1979). Sex ratio organisms (spiroplasmas) of Drosophila. In The Mycoplasmas, vol. 3, pp. 175-208. Edited by R. F. Whitcomb \& J. G. Tully. New York: Academic Press.

Williamson, D. L. \& Whitcomb, R. F. (1974). Helical, wall-free 
prokaryotes in Drosophila, leafhoppers and plants. Colloq INSERM 33, 283-290.

Williamson, D. L. \& Whitcomb, R. F. (1975). Plant mycoplasmas: a cultivable spiroplasma causes corn stunt disease. Science $\mathbf{1 8 8}$, 1018-1020.

Williamson, D. L., Whitcomb, R. F. \& Tully, J. G. (1978). The spiroplasma deformation test, a new serological method. Curr Microbiol 1, 203-207.

Williamson, D. L., Tully, J. G. \& Whitcomb, R. F. (1979). Serological relationships of spiroplasmas as shown by combined deformation and metabolism inhibition tests. Int $J$ Syst Bacteriol 29, 345-351.

Williamson, D. L., Steiner, T. \& McGarrity, G. J. (1983). Spiro- plasma taxonomy and identification of the sex ratio organisms : can they be cultivated? Yale J Biol Med 56, 583-592.

Williamson, D. L., Hackett, K. J., Wagner, A. J. \& Cohen, A. J. (1989). Pathogenicity of cultivated Drosophila willistoni spiroplasmas. Curr Microbiol 19, 53-56.

Williamson, D. L., Adams, J. R., Whitcomb, R. F., Tully, J. G., Carle, P., Konai, M., Bové, J. M. \& Henegar, R. B. (1997). Spiroplasma platyhelix sp. nov., a new mollicute with unusual morphology and genome size from the dragonfly Pachydiplax longipennis. Int J Syst Bacteriol 47, 763-766.

Williamson, D. L., Whitcomb, R. F., Tully, J. G. \& 10 other authors (1998). Revised group classification of the genus Spiroplasma. Int J Syst Bacteriol 48, 1-12. 